\title{
Rapid presumptive diagnosis of gonococcal urethritis in men by the limulus lysate test
}

\author{
VINCENT A. SPAGNA, RICHARD B. PRIOR, AND ROBERT L. PERKINS \\ From the Division of Infectious Diseases, Department of Medicine, The Ohio State University College of \\ Medicine, Columbus, Ohio, USA
}

SUMMARY In an evaluation of the limulus assay as a method for detecting endotoxin in urethral exudates, positive results for urethral samples at a 1/200 dilution were obtained from 73 out of 73 patients with culture-positive gonococcal urethritis while negative results were obtained from 26 out of 27 patients with culture-negative urethral specimens. A specimen from one patient, which gave negative results on Gram stain and culture, gave positive results to the limulus test. The overall accuracy of the limulus test for predicting culture results was $99 \%(P<0 \cdot 001)$. Thus, in preliminary studies of otherwise healthy men, the results of the limulus assay correlated with those of biological methods for diagnosing urethral gonorrhoea; the test may, therefore, be of use in identifying cases of nongonococcal urethritis.

\section{Introduction}

Studies in recent years (Melton, 1976; Felman and Scaffidi, 1977) have shown that gonorrhoea is the most common, reportable infectious disease in the United States. In 1976, there were one million reported cases of gonorrhoea (Venereal Disease Control Division, 1976), over 600000 occurring in men. Rapid and sensitive diagnostic methods are needed in the management of patients with gonococcal and nongonococcal urethritis (NGU). A variety of techniques for diagnosing gonococcal disease have been developed (Welch and O'Reilly, 1973; Jacobs and Kraus, 1975; Feng et al., 1977) but most are complex and generally require unavailable materials.

Pioneer studies (Levin and Bang, 1964) showed thai a lysate from washed amoebocytes of the limulus polyphemus, the horseshoe crab, formed a gel in the presence of minute amounts of endotoxin elaborated by Gram-negative bacteria. The limulus assay has been used for detecting endotoxin in blood (Levin et al., 1970), urine (Jorgensen et al., 1973), and joint and spinal fluids (Tuazon et al., 1977), and as a method for pyrogen testing of injectable commercial fluids (Jorgensen and Smith, 1973). The use of the limulus endotoxin assay in the diagnosis of

Address for reprints: Dr Vincent A. Spagna, Ohio State University Hospital, 410 West 10th Avenue, Columbus, Ohio 43210, USA

Received for publication 15 August 1978 gonococcal urethritis and as a possible means of identifying cases of NGU is the subject of this report.

\section{Material and methods}

\section{STUDY POPULATION}

One hundred men with uncomplicated urethritis seen at the Columbus Health Department Venereal Disease Clinic were studied. These patients had sought treatment because of urethral discharge or dysuria or both and were selected on a random basis; only those with a purulent urethral discharge or a discharge obtained after urethral massage were included. Patients receiving antibiotic therapy within 10 days of presentation were excluded. The mean age was 23.6 years and the range, 19-28 years. The pat:ents presented one to nine days after noticing symptoms, with a mean of $2 \cdot 8$ days.

\section{DIAGNOSTIC PROCEDURES}

Each patient underwent a standardised interview, concerning demography, sexual and venereal disease histories, and present illness, and an examination of the genitals and inguinal lymph nodes.

Urethral exudates $(0.05-0.1 \mathrm{ml})$ were obtained from the urethral meatus by gentle aspiration with a tuberculin syringe (without needle) and transferred to a pyrogen-free plastic test tube containing $1 \mathrm{ml}$ of pyrogen-free water. All specimens were frozen at $-20^{\circ} \mathrm{C}$ before being tested by the limulus assay. 
For culture purposes, a sterile, calcium alginatetipped, wire, urethrogenital swab (Wilson Diagnostics) or sterile, bacteriological loop was passed 3-4 $\mathrm{cm}$ into the urethra. The samples were streaked directly on to Thayer-Martin media and incubated for 48 hours at $35^{\circ} \mathrm{C}$ in $5 \%$ carbon dioxide. No cultures for viruses or chlamydiae were carried out.

The same procedure was repeated to obtain a specimen for Gram-staining and microscopical examination.

\section{LABORATORY METHODS}

Gram-stained smears of urethral exudate were examined under $\times 1000$ magnification oil immersion for the presence of polymorphonuclear cells and Gram-negative diplococci. (One microscope was used by one observer.) The results of the smears were considered positive if typical Gram-negative diplococci were seen, whether located intracellularly or extracellularly. A presumptive identification of isolates of Neisseria gonorrhoeae was based on characteristic colonial morphology, positive oxidase test, and the presence of Gram-negative diplococci. Isolates were further identified as $N$. gonorrhoeae by typical sugar fermentation reactions. The microscopical diagnosis of NGU required a mean of 10 leucocytes per $\times 1000$ field in a least five fields and the absence of Gram-negative diplococci.

\section{LIMULUS ASSAY}

Frozen specimens, of urethral exudate were thawed, vortexed, and diluted in pyrogen-free water to final dilutions of $1 / 20$ and $1 / 200$ of the original sample; $0.2 \mathrm{ml}$ of the diluted specimens was added to singletest Pyrotest ${ }^{\mathrm{TM}}$ vials (Difco, by courtesy of A. L. Lane), mixed incubated at $37^{\circ} \mathrm{C}$ in a water bath for one hour, and read. A firm opaque gel which remained adherent to the bottom of the vial when inverted through $180^{\circ}$ was interpreted as a positive test result; the absence of firm gelation was interpreted as a negative result. Known positive and negative control samples were also tested with each assay. The limulus assays were read without previous knowledge of the microbiological findings. The sensitivity of the limulus test was determined by the detection of less than $0.1 \mathrm{ng} / \mathrm{ml}$ Escherichia coli endotoxin.

\section{ANALYSIS OF DATA}

The results of the limulus assay, Gram-stained smears, and cultures were entered into a HewlettPackard Model 9825A programmable calculator for subsequent determination of correlation. Yates's $\chi^{2}$ method of analysis was used for the determination of statistical significance.

\section{Results}

A comparison of the results of the limulus assay for specimens at a 1/200 dilution with those of the Gram-stained smears of patients with and without culture-positive gonococcal urethritis are shown in the Table. Of 73 patients with culture-positive gonorrhoea, $73(100 \%)$ had positive limulus test results and $72(99 \%)$ positive Gram-stained smear results; of 27 patients with probable nongonococcal urethritis, $26(96 \%)$ had negative limulus test results and $27(100 \%)$ negative Gram-stained smear results $(\mathrm{P}<0 \cdot 001)$. Testing of the exudates at a $1 / 20$ dilution gave positive assay results in five $(19 \%)$ of the 27 patients with nongonococcal urethritis. On retesting at $1 / 100$ and $1 / 200$ dilutions, all the specimens gave negative results to the limulus assay. Only one patient with a negative smear result and a negative culture result for $N$. gonorrhoeae had a positive result to the limulus assay at a 1/200 dilution; on retesting, this specimen produced a positive result at a 1/800 dilution.

\section{Discussion}

The outer membranes of $N$. gonorrhoeae are known to contain protein, lipopolysaccharide, and loosely bound lipids (Johnston and Gotschlich, 1974; WolfWatz et al., 1975). Recently, Rice and Kasper (1977) have shown that gelation of limulus lysate was caused by the intact outer membranes of $N$. gonorrhoeae and each of its constituents at concentrations as low

Table Results of Gram-stained smears and limulus assay for patients with culture-positive gonococcal and nongonococcal urethritis

\begin{tabular}{|c|c|c|c|c|c|}
\hline \multirow[b]{2}{*}{ Diagnosis } & \multirow[b]{2}{*}{ No. of patients } & \multicolumn{2}{|c|}{ Gram-stained smears } & \multicolumn{2}{|c|}{ Limulus assay* } \\
\hline & & Positive & Negative & Positive & Negative \\
\hline \multirow{2}{*}{$\begin{array}{l}\text { Gonococcal } \\
\text { urethritis } \\
\text { Nongonococcal } \\
\text { urethritis }\end{array}$} & 73 & 72 & 1 & 73 & 0 \\
\hline & 27 & 0 & 27 & 1 & 26 \\
\hline
\end{tabular}

*Original sample diluted $1 / 200$ 
as $0.7 \mathrm{ng} / \mathrm{ml}$ of intact outer membrane, $0.08 \mathrm{ng} / \mathrm{ml}$ of protein fraction, and $0.16 \mathrm{ng} / \mathrm{ml}$ of lipopolysaccharide fraction. Thus, with the high sensitivity of the limulus assay for components of $N$. gonorrhoeae false-negative results for urethral samples would be unlikely to occur in cases of uncomplicated gonococcal urethritis. Our findings support this hypothesis. In those patients with culture-positive gonococcal urethritis dilutions of $1 / 200$ of the urethral samples produced positive limulus reactions consisting of solid, opaque gelation in every instance.

The potential aetiological agents in NGU have been the focus of recent intense bacteriological, virological, and serological studies (Holmes et al., 1975). The hypothesis that Chlamydia trachomatis and Ureaplasma urealyticum are the most common urethral pathogens in NGU has been supported by considerable evidence (Wong et al., 1977; Bowie, 1978). Corynebacterium genitale type 1 (Furness et al., 1977), and other bacteria (Bowie et al., 1977), herpesvirus hominis (Jeansson and Molin, 1960), and Trichomonas vaginalis (Catterall, 1960) have also been implicated as possible aetiological agents in NGU. Although documented evidence is lacking, it is possible that within the spectrum of agents associated with NGU some could elaborate substances which would produce positive limulus test results. The fact that $C$. trachomatis has a cell wall with antigenic properties similar to but not identical with that of Gram-negative bacteria (Kuo et al., 1977) supports that possibility. Compounds other than bacterial endotoxins (Elin and Wolff, 1973; Wildfeuer et al., 1974) can also give positive results to the limulus test.

Our observations indicated that such potential substances existed in the exudates of some of our patients with NGU. With the exception of one case, however, dilutions of $1 / 200$ of the urethral samples resulted in negative limulus reactions. One specimen showed no bacterial forms on a Gram-stained smear, was culture-negative for $N$. gonorrhoeae, and produced a positive limulus test result at a dilution of $1 / 800$. Further questioning of this patient with a false-positive result to the limulus test elicited that he had received antibiotic therapy for gonorrhoea on eight occasions in three years, had last been treated three months previously and had access to tetracycline. While the reasons for this discrepancy are speculative, the possibilities of sampling-error, unreported antibiotic usage, or contaminated (pyrogen-containing) equipment may provide an explanation.

In the present study, the results of the limulus test on diluted samples of urethral exudate correlated with those of bacteriological methods of diagnosis of urethral gonorrhoea in men with an overall accuracy of $99 \%$. These preliminary studies of otherwise healthy men with exudative urethritis suggest that the limulus lysate assay is rapid, reliable, and sensitive for the detection of $N$. gonorrhoeae and may assist in identifying cases of NGU. With this test as an adjunct to other diagnostic procedures, it may be possible to give specific treatment at the patient's initial visit even before culture results are available.

We are indebted to Dr James Curran, Dr Joseph Lossick, Dr Phum Si The, Ms Jeanne Gwynn, Ms Betty Huber, Mr Michael Smeltzer, Mr Courtland Storck, and Mr Paul Vangeloff of the Columbus Health Department Venereal Disease Clinic for their cooperation and assistance.

\section{References}

Bowie, W. R. (1978). Etiology and treatment of nongonococcal urethritis. Sexually Transmitted Diseases, 5, 27-33.

Bowie, W. R., Wang, S. P., Alexander, E. R., Floyd, J., Forsyth, P. S., Pollock, H. M., Lin, J. L., Buchanan, T. M., and Holmes K. K. (1977). Etiology of nongonococcal urethritis and related infections. In Nongonococcal Urethritis and Related Infections, p. 19-29. Edited by D. Hobson and K. K. Holmes. American Society for Microbiology: Washington DC.

Catterall, R. D. (1960). Diagnosis and treatment of trichomonal urethritis in men. British Medical Journal, 3, 113-115.

Elin, R. J. and Wolff, S. M. (1973). Nonspecificity of the limulus amebocyte lysate test-positive reactions with polynucleotides and proteins. Journal of Infectious Diseases, 128, 349-352.

Felman, Y. M. and Scaffidi, S. (1977). Reported gonorrhea trends in New York City, 1970 to 1975. New York State Journal of Medicine, 77, 1083-1089.

Feng, W. C., Medeiros, A. A., and Murray, E. S. (1977). Diagnosis of gonorrhea in male patients by culture of uncentrifuged firstvoided urine. Journal of the American Medical Association, 237, 896-897.

Furness, G., Evangelista, A. T., and Kaminski, Z. (1977). Corynebacterium genitalium (nonspecific urethritis Corynebacterium): biologic reactions differentiating commensals of the urogenital tract from the pathogens responsible for urethritis. Investigative Urology, 15, 23-27.

Holmes, K. K., Handsfield, H. H., Wang, S. P., Wentworth, B. B. Turck, M., Anderson, J. B., and Alexander, E. R. (1975) Etiology of nongonococcal urethritis. New England Journal of Medicine, 292, 1199-1205.

Jacobs, N. F. and Kraus, S. J. (1975). Gonococcal and nongonococcal urethritis in men-clinical and laboratory differentiation. Annals of Internal Medicine, 82, 7-12.

Jeansson, S. and Molin, L. (1960). Genital herpes infection and nonspecific urethritis. British Medical Journal, 3, 113-115.

Johnston, K. H. and Gotschlich, E. C. (1974). Isolation and characterization of the outer membrane of Neisseria gonorrhoeae. Journal of Bacteriology, 119, 250-257.

Jorgensen, J. H., Carvajal, H. F., Chipps, B. E., and Smith, R. F. (1973). Rapid detection of Gram-negative bacteriuria by use of the limulus endotoxin assay. Applied Microbiology, 26, 38-42.

Jorgensen, J. H. and Smith, R. F. (1973). Rapid detection of contaminated intravenous fluids using the limulus in vitro endotoxin assay. Applied Microbiology, 26, 521-524.

Kuo, C. C., Caldwell, H. D., Wang, S. P., and Grayston, J. T. (1977). Antigens of Chlamydia trachomatis. In Nongonococcal Urethritis and Related Infections, p. 176-185. Edited by D. Hobson and K. K. Holmes. American Society for Microbiology: Washington DC.

Levin, J. and Bang, F. B. (1964). The role of endotoxin in the extracellular coagulation of limulus blood. Bulletin of Johns Hopkins Hospital, 115, 265-274.

Levin, J., Poore, T. E., Zauber, N. P., and Oser, R. S. (1970). Detection of endotoxin in the blood of patients with sepsis due to Gram-negative bacteria. New England Journal of Medicine, 283, 1313-1316. 
Melton, L. J. (1976). Comparative incidence of gonorrhea and nongonococcal urethritis in the United States Navy. American Journal of Epidemiology, 104, 535-542.

Rice, P. A. and Kasper, D. L. (1977). Characterization of gonococcal antigens responsible for induction of bactericidal antibody in disseminated infection-the role of gonococcal endotoxins. Journal of Clinical Investigation, 60, 1149-1158.

Tuazon, C. U., Perez, A. A., Elin, R. J., and Sheagren, J. N. (1977). Detection of endotoxin in cerebrospinal and joint fluids by limulus assay. Archives of Internal Medicine, 137, 55-56.

Venereal Disease Control Division (1976). VD Fact Sheet, Department of Health, Education and Welfare, publication No. (CDC) 77-8195. US Printing Office, Washington DC.

Welch, B. G. and O'Reilly, R. J. (1973). An indirect fluorescent antibody technique for study of uncomplicated gonorrhea. I. Methodology. Journal of Infectious Diseases, 127, 69-76.
Wildfeuer, A., Heymer, B., Schleifer, K. H., and Haferkamp, O. (1974). Investigations on the specificity of the limulus test for the detection of endotoxin. Applied Microbiology, 28, 867-871.

Wolf-Watz, H., Elmros, T., Normark, S., and Bloom, G. D. (1975). Cell envelope of Neisseria gonorrhoeae outer membrane and peptidoglycan composition of penicillin-sensitive and resistant strains. Infection and Immunity, 11, 1332-1341.

Wong, J. L., Hines, P. A., Brasher, M. D., Rogers, G. T. Smith, R. F., and Schachter, J. (1977). The etiology of nongonococcal urethritis in men attending a venereal disease clinic. Sexually Transmitted Diseases, 4, 4-8. 